\title{
Arsenic and antimony speciation of historical roaster waste samples from the Giant Mine, Yellowknife, Canada
}

\author{
JULLIETA E. LUM ${ }^{1}$, JOYCE M. MCBETH ${ }^{1,2}$, DR.
}

VALERIE A. SCHOEPFER, PHD ${ }^{1}$, ANEŽKA BORČINOVÁ RADKOVÁ ${ }^{3}$, HEATHER E. JAMIESON ${ }^{3}$, MARY T.R.P. WALLS ${ }^{1}$ AND MATTHEW B. J. LINDSAY ${ }^{1}$

${ }^{1}$ University of Saskatchewan

${ }^{2}$ University of Regina

${ }^{3}$ Queen's University

Presenting Author: jullieta.lum@usask.ca

The Giant Mine has a legacy of arsenic contamination from mining and processing of gold-bearing arsenopyrite. Approximately 237,000 tonnes of $\mathrm{As}_{2} \mathrm{O}_{3}$ roaster waste (ATRW) were generated from 1952-1999 and stored in underground chambers. Knowledge of the waste geochemistry and mineralogy is essential for assessing its long-term stability and options for permanent remediation strategies. Previous studies hypothesized that Sb substitution for As in ATRW solids may affect ATRW geochemical characteristics and environmental behavior. Here, we examine ATRW samples from 9 of the 15 underground chambers to assess compositional heterogeneity and $\mathrm{As}$ and $\mathrm{Sb}$ speciation and coordination.

Bulk geochemical analyses indicate As dominates the ATRW with a wide range of $\mathrm{Fe}, \mathrm{Sb}, \mathrm{S}, \mathrm{Al}, \mathrm{K}$ and $\mathrm{Pb}$ concentrations among samples, and subtle variations in $\mathrm{Mg}, \mathrm{Ca}, \mathrm{Na}$ and $\mathrm{Cu}$. Xray diffraction and energy dispersive spectra analyses reveal that the waste is dominated by arsenolite $\left[\mathrm{As}_{2} \mathrm{O}_{3}\right]$, with minor to accessory $\mathrm{Fe}$ oxides (maghemite, magnetite, hematite, magnesioferrite), arsenopyrite, muscovite, clinochlore, quartz, gypsum, dolomite, and other phases that likely include scorodite $\left[\mathrm{FeAsO} \mathrm{O}_{4} \cdot 2 \mathrm{H}_{2} \mathrm{O}\right]$, arseniosiderite $\left[\mathrm{Ca}_{2} \mathrm{Fe}_{3} \mathrm{O}_{2}\left(\mathrm{AsO}_{4}\right)_{3} \cdot 3 \mathrm{H}_{2} \mathrm{O}\right]$, and yukonite $\left[\mathrm{Ca}_{7} \mathrm{Fe}_{12}\left(\mathrm{AsO}_{4}\right)_{10}(\mathrm{OH})_{2} \mathrm{O} \cdot 15 \mathrm{H}_{2} \mathrm{O}\right]$. The majority of As and $\mathrm{Sb}$ is hosted by arsenolite, with some As present in other phases. Arsenic K-edge XANES spectra indicate As(III) is dominant with varying proportions of $\operatorname{As}(\mathrm{V})$ and $\operatorname{As}(-\mathrm{I})$. All samples contain variable proportions of $\mathrm{Sb}(\mathrm{III})$ and $\mathrm{Sb}(\mathrm{V})$. The As K-edge EXAFS spectra are consistent with the local structure of arsenolite plus inner sphere complexation of As with $\mathrm{Fe}$ oxides. Sb K-edge EXAFS spectra are dominated by Sb-O, Sb$\mathrm{Fe}$ and $\mathrm{Sb}-\mathrm{As}$ bonds indicative of multiple solid-phase $\mathrm{Sb}$ hosts including senarmontite $\left[\mathrm{Sb}_{2} \mathrm{O}_{3}\right]$, tripuhyite $\left[\mathrm{FeSbO}_{4}\right]$ and $(\mathrm{As}, \mathrm{Sb})_{2} \mathrm{O}_{3}$.

Although these ATRW samples are dominated by arsenolite, the observed variability in solid phase mineralogy, oxidation state and molecular structure of $\mathrm{As}$ and $\mathrm{Sb}$ indicates the presence of distinct mineral phases whose geochemical behavior differs from arsenolite, an important consideration in assessing alternate chemical stabilization approaches. This study improves current knowledge of chemical heterogeneity within the chambers. It also sheds light on the As and $\mathrm{Sb}$ speciation and coordination environment in the ATRW, needed to predict relative solid-phase stabilities within the chambers and assess mobilization potential in long-term ATRW management. 